\title{
Climbing the Ladder of Success in the Imperial China: Chang Chien's Examination Life
}

\author{
Shun-Chih Sun \\ Department of Translation and Interpretation Studies, Chang Jung Christian University, Tainan, Chinese Taipei \\ Email: scsun16@hotmail.com
}

Received 7 August 2015; accepted 22 August 2015; published 28 August 2015

Copyright (C) 2015 by author and OALib.

This work is licensed under the Creative Commons Attribution International License (CC BY). http://creativecommons.org/licenses/by/4.0/

(c) $\underset{\text { EY }}{0}$ Open Access

\begin{abstract}
Chang Chien (1853-1926) was a native of Nant'ung, Kiangsu. In spite of the Various works on Chang Chien, which testify to the significance of his role in modern China, Chang Chien's examination life is still not well-researched. The purposes of this paper are firstly, to analyze Chang Chien's examination life systematically and clearly in the hope that it may become a useful reference for researchers on modern China, and secondly, to stimulate scholars for further research. This paper depends more on basic source materials rather than second-hand data. Among various source materials, Chang Chien's Diary, The Nine Records of Chang Chien and The Complete Work of Chang Chien are the most important. Chang Chien's examination life has close connection with the Imperial China's Civil Service examination and the establishment of New Education system of China in the late Ch'ing Period. Chang Chien's examination life can be divided into three periods: 1) The period to Siu-ts'ai diploma (licentiate). 2) The period to Chu-jen diploma (a successful candidate for provincial examination). And 3) The period to Chin-shih degree (a successful candidate for metropolitan examination).
\end{abstract}

\section{Keywords}

Examination Life, Civil Service Examination, Education

Subject Areas: Education, History

\section{Introduction}

\subsection{Review on the Research Outcome on Chang Chien and the Purposes of This Paper}

So far lots of scholars have done research on this topic; however, the answers to this question have not been completely discovered yet. Chang Hsiao-jo's Biography of Mr. Chang Chien of Nant'ung is a pioneer work 
which contains a great many source materials on this topic [1]. Sung Hsi-Shang's The Career of Chang Chien is less a biography than an annotated collection of source materials, drawn largely from Chang Chien's works, supplemented by personal remembrances, but touches little on "Climbing the ladder of success in the imperial China: Chang Chien's examination life” [2]. Liu Hou-sheng's Biography of Chang Chien concentrates on the political events of Chang Chien’s time [3]. Samuel C. Chu’s Reformer in Modern China: Chang Chien, 1853-1926 emphasizes Chang Chien's role in industry, education, land reclamation, water conservancy and his involvement in national affairs. This book also talks about Chang Chien's examination life [4]. Chang K'ai-yuan's Biography of Chang Chien discusses Chang Chien's career, political activities and Chang Chien's examination life [5]. Wang Tung-chin's Tradition and Perspective: A Research On Chang Chien's Economic Thought discusses Chang Chien's economic thought in detail [6]. Sun Shun-chih's “A Research On Chang Chien's Thought on Local Self-government” points out the fact that Chang Chien’s thought on Local self-government as: “Local self-government under gentry in promoting industry, education and other local affairs as a means of saving China; Local self-government as the basis of constitutional monarchy; and Local self-government as the basis of a republic" [7]. However, that article is too concise and too short in relation to "Climbing the ladder of success in the imperial China: Chang Chien's examination life”. Other works by Wong King-kong [8], Lee, Mabel [9], Chang P’eng-yuan [10], Koll, Elisabeth [11] Yu, Li-tzu [12], Sun, Shun-chih [13]-[15] also give some description about Chang Chien's examination life.

The first International Symposium on Chang Chien was held in Nanking University, Nanking, China from 24 to 28 August, 1987. Some sixty papers relating to Chang Chien's thought and activities on politics, industry, land reclamation, education etc. were presented [16]. The second International Symposium on Chang Chien was held in Nanking University, Nanking, China from 30 August to 2 September 1995. Some one hundred papers relating to Chang Chien's thought and activities on politics, industry, education, local self-government etc. were presented [17]. The third International Symposium on Chang Chien was held in Peking from 20 to 22 August 2000. Seventy-one papers relating to Chang Chien's thought and activities on politics, economy, education, culture and society etc. were presented [18]. The fourth international symposium on Chang Chien held in Nant'ung on the 25th-28th of November 2006, 88 articles in relation to Chang Chien and modern Chinese society had been submitted to this symposium [19]. And the fifth international symposium on Chang Chien held in Haimen on the 17th-19th of April 2009, 120 articles in relation to Chang Chien and Haimen: The Thoughts and Practice in the Early Period of Modernization had been submitted to this symposium [20], however, Chang Chien's examination life still has not been fully explored yet. The purposes of this paper are firstly, to analyze "Climbing the ladder of success in the imperial China: Chang Chien's examination life” systematically and clearly in the hope that it may become a useful reference for researchers on modern China, and secondly, to stimulate scholars for further research.

\subsection{Basic Materials}

I have adopted the content analysis method in this research and I have collected, arranged, compared and analyzed the related data to help reach a conclusion. This paper depends more on basic source materials rather than second-hand data. Among various source materials, Chang Chien's Diary [21] is the most basic one, which covers almost 53 years from 24 October, 1873, when he was twenty years three months and twenty three days, to 2 August, 1926, twenty two days before his death.

This diary contains approximately 875,000 words by which we are able to understand the life of a typical Chinese intellectual, to check the exact dates of some writings of his, and to correct errors against related sources. The first part of Chang Chien's diary which covers approximately the period from 1873 to 1892 was published in Taipei in 1967; and the second part of Chang Chien's diary which covers approximately the period from 1892 to 1926 was later published in Taipei in 1969. These two parts of Chang Chien's diary were reprinted together in 1986 in Taipei covering the period from 1873 to 1926. The Nine Records of Chang Chien [22] (Hereafter cited as Chiu-lu.) is an indispensable source material to Chang Chien's ideas and activities. This collection of his writings is divided topically into: Cheng Wen Lu (On Politics), Shih Yeh Lu (On Industry), Chiao Yu Lu (On Education), Tzu Chih Lu (On Self-government), Tz’u Shang Lu (On Philanthropy), Wen Lu (Essays), Shih Lu (Poems), Chuan Lu (Special Section), and Wai Lu (On the Civil Service Examination). Within each topical section the sources are arranged in Chronological order. The Complete Work of Chang Chien [23] [24], and Extant Writings of Chang Chien [25] include some new data not found in The Nine Records of Chang Chien, 
are invaluable source materials to "Climbing the ladder of success in the imperial China: Chang Chien's examination life".

\section{Imperial Civil Service Examination and the Development of New Style Education in China}

For close to two thousand years China had a gradually developing system of education based on the Confucian classics and formalized by the civil service examination system. Confucius (551 B.C.-479 B.C.) found that the natural hierarchy of men, based on differences in intelligence, ability, and moral character, came into direct conflict with the feudal hierarchy, based on status at birth. When Confucius' whole system of thought is analyzed, it is obvious that he regards rule by the wise and virtuous as the very foundation of good government. Mencius (371-289 B.C.), the foremost disciple of Confucianism, cited ancient practices which being legendary and beyond proof. He argued that it is the duty of the state to set up schools at various levels for the education of people, though we should realize that up to his lifetime education had practically been a monopoly of the hereditary feudal nobility. Han Fei (280 B.C.-233 B.C.), the synthesizer of the Legalists stress "the right man for the job" as well. Confucius, Mencius and Han Fei all had the idea of selecting the right men for the job. But how to realize this ideal? What is the objective way in selecting talents for government service? In the Han Dynasty, there was a system of "recommendation". Under this system, the high officials should recommend talents for government service. However, this recommendation system collapsed due to serious nepotism and did not function well later.

Finally, a system based on the "spirit of equality" in selecting talents for government service was invented in the Sui Dynasty, which matured in the T'ang Dynasty, namely, the civil service examination system. The civil service examination in the Ch'ing dynasty was modeled after that of the previous Ming dynasty. There were three major examinations leading to the top: local examinations, provincial examinations, and metropolitan examinations. Begin with the Hsien, Chou, and the Yuan examinations, the passing of which qualified one for the Sheng-yuan degree. And it was further divided into Fu-sheng, Tseng-sheng and lin-sheng (who received certain stipends), depending on the ranks on the list of successful candidates. Following the three lower examinations came the k'o (department) and Hsiang (provincial) examinations, usually held once every three years. A candidate who passed both these tests became a Chu-jen (Provincial Graduate), and qualified for minor official appointment. For those who failed the Hsiang examination, a Shui (annual) examination had to be taken the following year by which the candidates might upgrade their level of Sheng-yuan (for example from Tseng-sheng to lin-sheng) and even might change their status from Tseng-sheng to Kung-sheng that also qualified for minor official appointment; while those who passed the Hsiang examinations would leave for the capital city of Peking to take the Hui (metropolitan) examination which took place in the Spring following each Hsiang examination. Those who succeeded in the Hui examination were called Kung-shih, and took Fu-shih (a second examination) immediately. The handful who managed to get through to this point were guaranteed the top degree, since the last test, the Tien (Palace examination), served only to rank the candidates according to their talents. The top three scholars were honored with the respective titles of Chuan-yuan, Pang-yen, and T'an-hua. All the Chin-shih could expect some kind of official appointment as their reward [13].

Although the examination system was not absolutely equal, for example, in the preparation for examination, the poor simply could not afford to spend many years studying for examinations. Nevertheless, under this well designed civil service examination system, still a great deal of poor people had the chance to the ladder of success. And hence there was a Chinese proverb: "there are gold houses and beauties in the books" which meant once you had succeeded in the civil service examinations, you could get prestige, property, power, and women of great charm.

According to statistics collected by Pin-t’I Ho, from 1371 to 1904 in the Ming and Ch'ing dynasties, there were 14,562 Chin-shih degree holders. Among which 4,533 holders whose families during the three preceding generations had failed to produce a single holder of Sheng-yuan, let alone any office or official (31.1 percent); 1,689 holders whose families during the three preceding generations had produced one or more sheng-yuan but no holder of a higher degree or office (11.6 percent); and 8,340 holders whose families during the first three generations had produced one or more holders of higher degrees or offices (57.3 percent) [26]. Therefore the commoners still had the chance to become government officials through civil service examinations.

The civil service examination system was served as a means to stabilize the nation for the emperor as well. 
What it meant to the imperial government has been best expressed by an emperor of the T'ang dynasty, T'ang T'ai-chung, who at the sight of his new successful examination candidates jubilantly exclaimed, "The heroes of the world have fallen within the range of my arrow shot”. He knew well that through the examination system he had brought under control the free-ranging thought of the leading social group. The constant drilling in traditional Confucian moral principles and the writing of formalized essays kept the minds of gentry so occupied that they had little time for independent thought and study. Their thought was channeled into the lines of official ideology in which the aspects of authority and discipline in the Confucian tradition were emphasized. The principles of loyalty and service, which were fundamental parts of this doctrine, were stressed not only in the examinations themselves but also in the schools, which were related to the examination system [27]. Especially, during the nineteenth century, greatest stress was laid in the examinations on literary style and calligraphy, at the expense of knowledge and understanding.

The basic validity of this system was seriously challenged by the Chinese educated class in the nineteenth century, when repeated political and military disasters led some to attribute China's weakness to the formal structure of her educational system. Little by little some Chinese came to recognize that the system itself was inadequate to cope with China's problems. For example, Hsueh Fu-cheng, Yen Hsiu, K'ang Yu-wei, Yen Fu, Liang Ch'i-ch'ao, Chang Chih-tung, and Ch'en Pao-chen all expressed their concerns about this system [13]. Chang Chien's first attempt to advise the government in education affairs was in the lengthy document entitled "Reasoned Discussion on Reforms", which he submitted in 1901, he made the following suggestions on education: "1) Establishment of a public education system, starting with primary education and then proceeding upward. 2) Changing the examination system to conform to the new education system. 3) Introduction of the teaching of drawing and cartography in primary schools. 4) Establishment of provincial translation bureaus. 5) Creation of a national ministry of education. 6) Rewarding graduates of the new system by granting them the traditional titles along with their prestige and privileges (Chiu-lu, Chen Wen Lu, chuan 2, 12a - 16a).

The disastrous consequences of the Boxer uprising of 1900 finally forced the Empress Dowager and her conservative advisers to institute reforms. Officials both at the Court and the provinces were ordered to submit memorials on the ways and means of bringing about reform. Eventually an imperial decree of 2 September 1905 ordered that the provincial and metropolitan examinations be halted, effective with the test scheduled for 1906 while lower examinations were also to end at once [28].

\section{Early Life and Chang Chien's Examination Endeavor}

Chang Chien (1853-1926), tzu (courtesy title) Chi-chih, hao (alias) Se-an, and Se-Weng, was born the fourth of five sons, on July $1^{\text {st }}, 1853$ in the village of Ch'ang-lo, Hai-men, Kiangsu, China, and died on August $24^{\text {th }}, 1926$ in Nant'ung, Kiangsu, China. Chang Chien began his student days in 1856 at the age of only four. His first teacher was his father Chang, P'eng-nien, who taught him to read Book of a Thousand Characters. The following year, 1857, Chang Chien was sent to a village school. The teacher was Ch'iu, Ta-chang, under whom Chang Chien in a period of seven years (1857-1863), had finished the primers such as Trimetric Classics, and Books of Family Names; the basic poetic readers such as Works of A Thousand Poets, and Poems of A Boy Prodigy; and the Confucian Classics such as The Great Learning, The Doctrine of Golden Means, The Analects of Confucius, Mencius, The Filial Piety Classic, and The Book of Odes.

In 1864, his father employed Sung, Hsiao-ch'i as family teacher to help Chang Chien and his brothers in the preparation for local examinations. The teacher asked Chang Chien to study again The Great Learning, The Doctrine of Golden Means, The Analects of Confucius, and Mencius, but from better editions. Then he proceeded to teach the boy The Book of History, The Book of Change, The Book of Rites, and T'so's Commentary of the Spring and Autumn Annals. Under his teacher's effective guidance, Chang Chien learned to write examination poems and examination essays which were required in the examinations. Unfortunately, this enthusiastic teacher died in the summer of 1866, and Chang Chien was sent to follow Sung Lin, the dead teacher's nephew, in a neighboring village, Hsi T'ing. Under the new teacher, Chang Chien advanced to study two more Confucian classics, The Rite of Chou and The Book of Ritual (Chiu-lu, Chuan Lu, chuan 6, 2a - 4b).

\subsection{Licentiate Stage}

Chang Chien's examination life was a long and toilsome history. In the first stage, Chang Chien was lucky enough. He spent only five years, 1864-1868, in preparation, successfully passed through the district, prefectural, 
and Yuan (one conducted by provincial literary examiners) examinations, placing twenty-sixth in the latter, and was classified a Fu-sheng (Licentiate) in 1868, at the age of sixteen [1].

It was then necessary for promising youth whose ancestors in the three previous generations had not been scholars to have lawful guarantors and co-guarantors in order to qualify for examination. Since Chang Chien's family came from farming stock, he had to comply. There was no lack of willing guarantors, but his father trusted Chang Chien's tutor, Sung P'u-chai explicitly. And when the latter suggested that Chang Chien would do well to take examinations under an assumed relationship with a certain Chang Chiung in the neighboring district of Jo-kao, Chang P'eng-nien agreed to the deception. Chang Chien therefore took his early examinations in Ju-kao under the name of Chang Yu-ts'ai, Chang Chiung turned out to be a complete unscrupulous individual, and with the connivance of venal officials, blackmailed Chang Chien's family out of large sum of money and caused it no end of trouble. Fortunately there came to the aid of the hard-pressed father and son several staunch friends, among whom were Chang Chien's new tutor, Chao P'eng-yuan and magistrate Sun Yun-chin. It was largely through their efforts that Chang Chien was allowed to register his Sheng-yuan degree in his own native district and assumed his original name, Chang Chien (Chiu-lu, Chuan Lu, chuan 3,1a - 11b).

\subsection{Successful Provincial Candidate Stage}

The second stage Chang Chien spent seventeen more years, 1869-1885, failed five times in the provincial examinations. In 1870 he tried for Chu-jen degree for the first time, and succeeded in placing sixteenth in the k'o examination but failed to pass the provincial examination. He was repeated this pattern of succeeding in the k'o examination and failing in the provincial examinations four more times in 1873, 1875, 1876, and 1879. These repeated failures were especially galling to Chang Chien, since he won the top position in both the Kiangsu k'o examinations of 1876 and 1879, advancing from the classification of Fu-sheng to that of lin-sheng in 1876. Also during the same period he successively came through as the top man in the examinations of two local academies of 1874, sui examinations of 1877, and the examinations of three special academies of 1879. As Samuel. C. Chu describes: "The degree of Chiu-jen continued to elude him until 1885, when he competed in the provincial examination and succeeded in placing second highest among those who passed. He was then thirty-two" [4].

\subsection{Chin-Shih Stage}

Chang Chien spent nine more years, 1886-1894, in preparation, failed repeatedly four times in the examinations for Chih-shih degree in Peking in 1866, 1889, 1890, and 1892. In 1894, a special metropolitan examination was to be held in Peking in honor of the sixtieth birthday of the Empress Dowager. It was his brother, Chang Ch'a, who urged his father to press Chang Chien again and hence Chang Chien reluctantly accepted the order and set out to Peking to make a last effort for his family's prospect rather for his own interests. This time his name was found in the sixtieth position. He improved on this in the re-examination by placing tenth, and when the palace examination was over, he was chosen to be Chuan-yuan, the highest of all. He was duly appointed a Compiler of the First Class in the Hanlin Academy [4].

Unfortunately, only six months after he had won the highest title of Chuan-yuan, he lost his father, who had played the most important role in his examination life. Four years later, in 1898, when he had decided to take no office in the government and when he was busy promoting local development in his home area, Chang Chien did not forget to come back to Peking for his last examination in Hanlin Academy. According to himself, this unnecessary effort was again to fulfill the dream of his deceased father (Chiu-lu, Wen Lu, chuan 8, 6b).

Chang Chien's examination life was a good example showing how the traditional system affected the youth of the scholar-gentry in China. Chang Chien had been preoccupied with his examinations for a long period of time, from the age of twelve to forty-six, not including his primary school days from four to eleven. The Sheng-yuan (Hsiu-t'saiu) degree took him five years; Chu-jen seventeen more years; Chin-shih nine more years, and finally the Hanlin Academy examinations four more years (though during which Chang Chien mainly devoted himself in local development). Altogether thirty-five years, almost half of his eventual life time had been consumed when he finished the whole process of government examinations for gentry status and a civil appointment [Chiu-lu, Wen Lu, chuan 8, 6b - 7a].

Traditionally, a man with the title of Chuang-yuan in imperial China would continue to pursue an official career. Chang's case however was an exception. Although he had been appointed as a member of the Hanlin Academy in 1894 shortly after his success in the metropolitan examinations, he was determined to turn away 
from the government service. There were multiple factors which led Chang to abandon that career.

First of all, his father's death shortly after his remarkable success in the metropolitan examinations made him, a dutiful son, felt hollow and apathetic toward fame and position. Secondly, traditional scholars in China were sometimes names Shu Tai-tsu (studious idiot or pedants) for being useless in practical affairs. Chang Chien had a strong desire to change this sort of stereotype and meanwhile to set an innovative example for all scholars. Thirdly, while in Peking in 1894, he happened to witness a ridiculous scene. He saw officials, including aged ones, kneeled in the mud under a heavy downpour of rain to meet the palanquin of the Empress Dowager who did not even deign to acknowledge their homage. This experience awakened Chang Chien to the fact that even high officials were at the whim and mercy of the throne. And finally, during the Sino-Japanese war, when he was in mourning for his father in Nant'ung, Chang Chien had met Chang Chih-tung who was in Nanking temporarily serving as govern-general of Liang-Kiang. Coincidentally, at that time Chang Chih-tung was seeking to develop industry by persuading members of the local gentry to establish cotton mill. The humiliating term of the treaty of Shimonoseki, concluded in April 1895 was a shock to Chang Chien. With the encouragement of Chgang Chih-tung, Chang Chien therefore began the task of establishing a textile mill in Nant'ung. Thereafter until his death, he devoted himself to the cause of industry, education and other local affairs of self-government as the foundation of a constitutional monarchy, and then, a republic [13].

\section{Conclusion}

Chang Chien's examination life can be divided into three periods: 1) The period to Siu-ts'ai diploma (licentiate). 2) The period to Chu-jen diploma (a successful candidate for provincial examination). And 3) The period to Chin-shih degree (a successful candidate for metropolitan examination). The year 1894 was the watershed for Chang Chien. Before that, although he also served as government clerk, private secretary, local gazetteer and head of Academies, his behavior initially was more academic based act, and Chang Chien's main concern was to pass the imperial civil service examinations, the ladder of success in the imperial China. However, after his success in the imperial service examinations, Chang Chien had turned his time and energies to the cause of a series of problems related to the modernization of China. These included industrial growth, land reclamation, salt reform, river conservancy, modern education, civic and philanthropic projects, and constitutional governments, and he had made great contributions to China's modernization. As mentioned above, there were multiple factors which led to Chang Chien's change: his father's death, his desire to set an innovative practical-based example for all scholars, his refusal to the whim and mercy of the throne, and his acceptance of Chang Chih-tung's offer to establish a cotton mill in his home district of Nan'tung.

\section{References}

[1] Chang, H.-J. (1930) Nant’ung Chang Chi-chih Hsien-sheng Chuan-chi (Biography of Mr. Chang Chien of Nant’ung). Chung Hua Bookstore, Shanghai, 25-26.

[2] Sung, H.-S. (1963) Chang Chien te Shengp'ing (The Career of Chang Chien). Chinese Books Compilation Commission, Taipei.

[3] Liu, H.-S. (1958) Chang Chien Chuan-chi (Biography of Chang Chien). Shanghai Lung Men Joint Bookstore, Shanghai.

[4] Chu, S.C. (1965) Reformer in Modern China: Chang Chien, 1853-1926. Columbia University Press, New York and London, 10, 11.

[5] Chang, K.-Y. (2000) Chang Chien Chuan (The Biography of Chang Chien). China Industry and Commerce Associated Press, Beijing.

[6] Wang, T.-C. (2005) Ch’uang-t’ung yu Ch’ian-chan: Chang Chien Ching-chi Ssi-hsiang Yen-chiu (Tradition and Perspective: A Research on Chang Chien's Economic Thought). People’s Press, Beijing.

[7] Sun, S.-C. (2015) A Research on Chang Chien's Thought on Local Self-Government. Open Access Library Journal, 2, e1381. http://dx.doi.org/10.4236/oalib.1101381

[8] Wong, K.-K. (1957) Chang Chien: A Case Study of Attempts at China’s Modernization by the Traditional Gentry. Unpublished Master Thesis, University of Washington, Seattle.

[9] Lee, M. (1966) The Development of Exalt Commerce in Late Ch'ing Thought. Unpublished Ph.D. Thesis, The University of Sydney, Sydney.

[10] Chang, P.-Y. (1968) The Constitutionalists. In: Wright, M.C., Ed., China in Revolution: The First Phase 1900-1913, 
Yale University Press, New Heaven and London, 143-183.

[11] Koll, E. (2003) From Cotton Mill to Business Empire: The Emergence of Regional Enterprises in Modern China. Harvard University Asia Center, Cambridge, MA.

[12] Yu, L.-T. (2007) Tung-fang Wu-tuo-ban: Modern Nant’ung (Oriental Utopia: Modern Nant’ung). People’s Press, Peking.

[13] Sun, S.-C. (1991) Chang Chien (1853-1926): Political Thought and Action. PhD Thesis, University of New South Wales, Sydney, Shi-Ying Publisher, Taipei, 147-148, 152-153, 39-42.

[14] Sun, S.-C. (2013) On Chang Chien's Change from a Constitutional Monarchist to a Republican-Political Thought with Flexibility as the Underlying Reason. Global Journal of Human Social Science Political Science, 1, 1-15.

[15] Sun, S.-C. (2014) Chang Chien’s Middle Way for Gradual Reform. Global Review of History and Political Science, ARIPD, 2, 93-109.

[16] Yen, H.-H. (Ed.) (1993) Lun Chang Chien: Chang Chien Kuo-chi Hsuehshu Yen-t’ao-hui Lun-wen-chi (On Chang Chien: Collection of the International Symposium on Chang Chien). Kiangsu People’s Press, Nanking.

[17] Yen, H.-H. (Ed.) (1996) Chin-tai kai-ke-chia Chang Chien: Ti-erh-chieh Chang Chien Kuo-chi Hsuehshu Yen-t’ao-hui Lun-wen-chi (On Chang Chien: Collection of the Second International Symposium on Chang Chien). Kiangsu People’s Press, Nanking.

[18] T.s’ui, C.-C. (Ed.) (2001) Chung-kuo Tsao-ch’I Hsien-tai-hua te Ch’ien Ch'u: Ti-san-chieh Chang Chien Kuo-chi Hsuehshu Yen-t'ao-hui Lun-wen-ch (The Pioneers in the Early Period of China's Modernization: Collection of the Third International Symposium on Chang Chien). Chinese Industry and Commerce Joint Press, Peking.

[19] Chang, C., International Symposium Committee (Ed.) (2007) Chang Chien yu Chin-tai Chung-kuo She-hui--Ti ssu-chieh Chang Chien Kuo-chi Hsuehshu Yen-t’ao-hui Lun- wen-chi (Chang Chien and Chinese Society-The Fourth International Symposium on Chang Chien). Nanking University Press, Nanking.

[20] Ts’ui, C.-C. (Ed.) (2010) Chang Chien yu Haimen: Tsao-ch’I Hsien-tai-hua Ssu- hsiang yu Shih-Chien (Chang Chien and Haimen: The Thoughts and Practice in the Early Period of Modernization). Nanking University Press, Nanking.

[21] Chang, C. (1986) Liu-hsi Ts’ao-t’ang Jih-chi (Chang Chien’s Diary). Wen Hai Press, Taipei.

[22] Chang, H.-J. (Ed.) (1983) Chang-chi-tzu Chiu-lu (The Nine Records of Chang Chien). Wen Hai Press, Taipei.

[23] Chang, C., Research Center (Ed.) (1994) Chang Chien Ch’uan-chi (The Complete Work of Chang Chien). Kiangsu Classic Books Press, Kiangsu.

[24] Li, M.-H. and Yu, S.-W. (Eds.) (2012) Chang Chien Ch’uan-chi (The Complete Work of Chang Chien). Shanghai Dictionary and Books Press, Shanghai.

[25] Yang, L.-C. and Shen, W.-P. (Ed.) (1987) Chang Chien Ts'un-kao (Extant Writings of Chang Chien). People’s Press, Shanghai.

[26] Ho, P.-T. (1967) The Ladder of Success in Imperial China: Aspects of Social Mobility, 1368-1911. Columbia University Press, New York, 107-108, 112-113.

[27] Chang, C.-L. (1955) The Chinese Gentry: Studies on Their Role in Nineteenth Century Chinese Society. University of Washington Press, Seattle, 197-198.

[28] Ferguson, J.C. (1906) The Abolition of the Competitive Examinations in China. Journal of the American Oriental Society, 27, 79-87. http://dx.doi.org/10.2307/592849 